\title{
HISTÓRICO E ASPECTOS LEGAIS DA ADOÇÃO NO BRASIL
}

\author{
Dilce Rizzo Jorge *
}

\begin{tabular}{l|l|} 
& RBEn/02 \\
\hline
\end{tabular}

JORGE, D.R. - Histórico e aspectos legais da adoção no Brasil. Rev. Bras. Enf., RJ, $28: 11-22,1975$

\section{INTRODUÇÃO}

A legislação brasileira referente ao Instituto de Adoção, embora a passos lentos, evoluiu consideravelmente desde o primeiro Código Civil de 1916. Em 1957 a Lei Federal n. ${ }^{\circ} 3.133 / 57$ modificou alguns artigos do Código Civil referentes adoção e, em 1955 a Lei n. $.^{\circ} 4.655 / 65$, que dispõe sobre a Legitimidade Adotiva, veio proporcionar grandes benefícios tanto para os adotantes como para os adotados.

O conhecimento da legislação de adoção é importante para os profissionais da saúde, principalmente para aqueles que lidam com pessoas que apresentam problemas relacionados à esterilidade. Todavia ela é pouco conhecida pela maioria desses profissionais, os quais são, freqüentemente, solicitados para orientar pessoas que desejam adotar crianças e pessoas que desejam oferecer seus filhos para adoção. Isto acontece na enfermagem, com maior freqüência no campo da obstetrícia. A enfermeira poderia orientar e encaminhar os inte- ressados às autoridades competentes, inclusive informando quem pode simplesmente adotar ou realizar a legitimação adotiva.

Com o propósito de verificar o nível de conhecimento do pessoal de enfermagem foi aplicado o questionário a um grupo de 130 enfermeiras e obstetrizes. Verificou-se que: $60 \%$ recebe solicitação freqüente para "arranjar uma criança"; $97,7 \%$ desconhece a legislação pertinente; $97 \%$ desconhece o processo legal da adoção e $90 \%$ não recebeu orientação sobre o tema nos seus respectivos cursos de graduação, em enfermagem e em obstetricia.

Considerando o problema evidenciado pelas respostas ao questionário, e ainda a inexistência de publicação a respeito do assunto, na Revista Brasileira de Enfermagem, decidimos elaborar um trabalho que pudesse, não só informar, mas também despertar o interesse das enfermeiras e obstetrizes para tão relevante problema.

* Docente da Escola de Enfermagem da Universidade de São Paulo. 
JORGE, D.R. - Histórico e aspectos legais da adoção no Brasil. Rev. Bras. Enf., RJ, $28: 11-22,1975$

O tema é complexo e apresenta vários aspectos discutíveis, mas este trabalho tratará somente da evolução histórica do Institu.to de Adoção através dos séculos e da evolução do Instituto da Adoção no Brasil, bem como das penalidades impostas pelo Código Penal aos crimes contra o estado de filiação.

\section{CONCEITO DE ADOÇÃO}

"Adoção é um contrato solene que cria entre duas pessoas relações iguais às que resultariam de filiação legítima ou verdadeira".

A definição expressa bem que a adoção é um ato pelo qual uma pessoa passa a considerar como seu, o filho de outra pessoa.

CLÓVIS BEVILACQUA, eminente jurista brasileiro, no seu livro "Em defesa do Projeto de Código Civil", escreveu:

“... o instituto da adoção, tinha uma alta função social a desempenhar como instituição de beneficência destinada a satisfazer e desenvolver sentimentos afetivos do mais doce matiz, dando filhos a quem não teve a ventura de gerá-los, e desvelo paternais a quem privado deles pela natureza estaria talvez condenado, sem ela a descer pela escada da miséria, e ao abismo dos vícios e dos crimes".

e reafirma suas idéias depois de entrar em vigor o Código Civil.

“O que é preciso porém salientar é a ação benéfica social e individualmente falando, que a adoção pode exercer na sua fase atual. Dando filhos a quem não os tem por natureza, desenvolve sentimentos afetivos do mais puro quilate e aumenta na sociedade o capital de afeto e de bondade necessário ao seu aperfeiçoamento moral".

\section{BREVE HISTÓRICO DA ADOÇÃO ATRAVÉS dOS SÉCULOS}

O Instituto da Adoção é conhecido desde tempos remotos por egípcios, ba- bilônios, assírios, caldeus e hebreus. No Egito, Moisés foi adotado pela filha do Faraó, que lhe deu seu nome, mas, depois de adulto recusou-se ser chamado filho da filha do Faraó. O Códifgo Hamurabi $2.283-2.241 \mathrm{AC}$ contém regulamentação minuciosa a respeito da adoção, que foi praticada, amplamente, na Mesopotamia, em Atenas e no Egito. Entre os judeus, Jacob adotou Efraim e Manasses, filho do seu filho José. No Genesis, capítulo 48, versículo 5, sentencia o Patriarca Jacob "os teus filhos, que te nasceram na terra do Egito, antes que eu para aqui viesse a ti no Egito, são meus: Efraim e Manassés serão meus, como Rubens e Simeão. Mas a tua descendência que gerarás depois deles. será tua; segundo o nome de um de seus irmãos serão chamados na sua herança".

A maioria dos historiadores declara ser a adoção orginária de uma necessidade religiosa. Os povos antigos mantinham o culto aos mortos e tinham dias determinados para eles. As oferendas durante o culto, deveriam partir das pessoas da família. Em cada residência grega ou romana existia um altar com a chama de fogo sagrado, que devia ser renovado dia e noite, e ao chefe da família cabia o dever de fazê-lo. O pai dava a seu filho, juntamente com a vida, a crença. o culto, o direito e o dever de conservar o fogo doméstico, de oferecer as refeições fúnebres, de observar fórmulas culturais e recitar as orações sagradas.

Por esse motivo o celibato era condenado, e a esterilidade era motivo para divórcio. Conta. A. DE SOUZA PINTO, citando Aulogellio que:

"o primeiro divórcio que houve em Roma, no ano 523 desta cidade, foi o de Spurio Corvillio, pessoa nobre que, embora amando ternamente a esposa, com a qual viveu na harmonia mais perfeita, repudiou-a afinal a despeito de seus mais ardentes e cordiais sen- 
JORGE, D.R. - Histórico e aspectos legais da adoção no Brasil. Rev. Bras. Enf., RJ, $28: 11-22,1975$

timentos, somente porque ela era estéril, quando ele se casara no intuito jurado de ter filhos".

O direito de adotar era um recurso facultado às famílias a fim de evitar o seu desaparecimento, o que era então considerado como grande desgraça.

No Código de Manu, legislador hindu, encontra-se a seguinte frase:

"Aquele a quem a natureza não deu filhos poderá adotar um a fim de que os fúnebres cerimoniais não cessem por semelhante fato".

Entre os gregos só podia adotar quem não tivesse filhos. Entre os romanos não existia essa exigência e a adoção era realizada por meio de um cerimonial sacro, que se assemelhava ao nascimento de um filho - o adotado renunciava ao culto da família antiga, cortando os laços que o ligavam a ela e era introduzido no culto da família adotiva. Mais tarde surgiu a adoção testamentária, fórmula preferida por Cesar na adoção de Octávio. Justiniano simplificou o Instituto, criando a "adoção minus" e a "adoção plena".

$\mathrm{Na}$ "adoção minus" havia somente parentesco civil entre o adotado e o adotante, permanecendo o adotado com todos os seus direitos na família, mas sob a autoridade do pai natural. Não havia rutura com os pais naturais e era assegurado o direito de herdar, do adotante.

$\mathrm{Na}$ "adoção plena" (adoção entre parentes), além do parentesco civil que estreitava o natural, transferia-se o pátrio poder.

Muitos filhos adotivos foram imperadores: Scipião Emiliano, Cesar Otaviano, Calígula, Tibério, Nero, Justiniano. No fim da República, Claudio, para chegar ao tribunato, fez-se adotar por um plebeu e Galba adotou Pison, um homem do povo, para que pudesse continuar as tradições do seu governo.

$\mathrm{Na}$ Idade Média a adoção não foi acei- ta porque os aristocratas não queriam que suas heranças se desviassem da linha parental e a igreja considerava pouco favorável ao instituto do casamento.

Em 1789, com a Revolução Francesa, o Instituto da Adoção readquiriu o seu antigo vigor na Constituição Francesa, de 1873.

Napoleão Bonaparte regulamentou o Instituto, no Código Civil Francês de 1804, tomando como base o Direito Romano. Estabeleceu as seguintes condições: idade do adotante -40 anos; ausência de prole legítima ou legitimada, adotante 15 anos mais velho do que o adotado, conservação do direito do adotado em sua família natural e, no caso do adotante casado, consentimento do outro cônjuge.

O Código Civil Francês, que serviu de modelo aos países da Europa e das Américas, deve ter influenciado também na legislação da adoção

A maioria dos povos cultos a admite, porém, com restrições remanescentes do direito romano, que aceitava a adoção como último recurso para evitar o aniquilamento da família.

\section{EVOLUÇÃO DO INSTITUTO DA ADOÇ̃̃O}

Antes do Código Civil Brasileiro, a adoção era entre nós, regida pelo direito romano, como subsidiário do pátrio

BEVILACQUA (1923) diz que:

"a adoção antes do Código Civil, encontrava em nossas leis simples referências mantendo o instituto; não lhe davam organização completa. Os autores corriam ao direito romano para preencher as lacunas do direito pátrio. Criando a adoção a condição de filho não podia ser revogada por testamento. Além disso a adoção não era um ato puramente particular, nela intervinha a autoridade pública para completar pela confirmação do juiz como determinava a lei de 22 de setembro de 1828 , art. $1 .^{\circ "}$. 
JORGE, D.R. - Histórico e aspectos legais da adoção no Brasil. Rev. Bras. Enf., RJ, $28: 11-22,1975$

LEME (1963) diz que:

"no direito anterior, deviam as cartas de legitimação e de adoção ser homologadas judicialmente. A "Ord", Livro I, Título III, n. ${ }^{\circ}$, dava essas atribuições aos Desembargadores do $\mathrm{Pa}-$ ço; mas a lei de 22 de setembro de 1828, extinguindo os Tribunais dos Desembargadores do Paço, e da Consciência e Ordens, passou essas atribuições para os juízes de primeira instância, como se vê no parágrafo $1^{\circ}$ "verbis": "Aos juízes de primeira instância, procedendo as necessárias informações, audiência dos interessados havendo-os conforme o disposto no Regimento dos Des. do Paço, e mais leis existentes com recurso para a relação do Distrito, compete: conceder cartas de Legitimação a filhos legítimos e confirmar as adoções".

Segundo MONCORVO (1926) a primeira legislação no Brasil referente ao Instituto da Adoção, data de 1693. Referia-se a lei ao desamparo das crianças deserdadas da sorte no Rio de Janeiro, chamadas de expostos, cuja situação era precária e que com freqüência eram encontradas nas ruas. O Governo não dispunha de recursos para ampará-las e muitas eram recolhidas e criadas por famílias caridosas

Em 1738, por Ordem Régia de 10 de maio, foi criado o "Sistema de Rodas" a ser instalado em todas as cidades e vilas (1). Tinha a Roda um empregado para receber as crianças e dar parte ao Magistrado da localidade e este as fazia entregar às amas para criá-las. As amas eram pagas a custa dos rendimentos das Câmaras e dos cabeções das Sisas ou entregando às Misericórdias onde elas existissem; e como medida complemen- tar impunha-se às Santas Casas de Misericórdia a obrigatoriedade de elegerem anualmente o Mordomo dos Expostos, que era um empregado, conforme a lei, a fim de receber as crianças e entregálas a quem as quizesses adotar.

Parece que a Roda não atendeu à imposição dos princípios humanos vigentes porque, segundo a Fala do Trono em 1823, D. Pedro afirmava que de 12.000 recolhidos em 13 anos, somente 1.000 haviam vingado.

O Comendador Albino José da Silva, Provedor da Santa Casa de Misericórdia do Recife, no relatório bienal de 18981900 que enviou à Junta Administrativa, a ela se refere:

\section{“Casa dos Expostos}

Este estabelecimento continua a cargo das dignas filhas de São Vicente de Paulo, em número de doze, sob a direção da Irmã Rodicq, de cuja dedicação, cumpre-me dar o testemunho.

A direcção espiritual está ainda confiada aos Revs. Padres Lazaristas, nada me cabendo acrescentar ao já bem conhecido desempenho desse importante serviço, do qual é superior o Rev. Padre Arsenio Vuillemin, que por si só seria uma garantia para atestá-lo.

O serviço clínico também nenhuma alteração sofreu, continuando encarregado dele 0 Dr. Augusto Coelho e respectivo substituto Dr. Manoel Clementino de Barros Carneiro.

A roda dos enjeitados está ainda colocada nesta cidade, entregue a uma empregada, a quem incumbe remeter as crianças recolhidas ao estabelecimento, que delas deve tomar conta e entregá-las as damas de criação, as quais, embora sob a fiscalilização da superiora do mesmo esta-

(1) O Sistema de Rodas começou na Itália e sempre foi combatido pelos Sociólogos. Em 1863 foi abolida na Itália e nessa época poucos países da Europa tinham Rodas funcionando. No Brasil foi abolida em 1923. A Roda funcionava da seguinte forma; num paredão de rua, do prédio destinado a receber as crianças, havia um buraco fechado pela parte trazeira por uma espécie de redoma. Ninguém era visto do lado de fora e nem de dentro. Havia uma campainha do lado de fora que, quando tocada, o empregado rodava a parte aberta da redoma para o lado de fora e lá era colocado a criança. Em São Paulo, a roda da Santa Casa de Misericórdia funcionava no paredão da rua $\mathrm{D}$. Veridiana. 
JORGE, D.R. - Histórico e asjectos legais da adoção no Brasil. Rev. Bras. Enf., RJ, $28: 11-22,1975$

belecimento não oferecem as garantias, que que seria para desejar. No sentido de melhorar esse serviço já alguma cousa foi lembrada, como disse no Relatorio passado, mas ainda nada se pode realizar. Uma fiscalização que pudesse ser exercida sobre essas amas, pondo-as sob as vistas imediatas das Irmãs, encarregadas da administração, preveniria sem duvida que as crianças ficassem sujeitas a contrair hábitos e costumes, que poderão resultar de uma criação e educação prestadas, por gente rude, a quem faltam verdadeiros cuidados maternos, e havendo quasi sempre apenas o móvel do interesse mercenário.

A mordomia do estabelecimento foi zelosamente exercida durante o biênio findo pelo nosso digno colega, Coronel Apollinario Florentino de Albuquerque Maranhão".

O Sistema de Rodas foi combatido e condenado, mas somente em 1923, pelo Decreto $n .^{\circ} 16.300$, de 31 de dezembro, foi proibido o seu funcionamento. Apesar desse decreto, ainda funcionaram as rodas por muito tempo, como por exemplo, a Santa Casa de Misericórdia de São Paulo, que a extinguiu em 1948.

Decorridos quatro anos da lei que extinguia a Roda, o Decreto 17.943, de 2 de outubro de 1927, consolidou e reuniu num Código de Menores as leis de assistência e proteção à infância, e diz no seu artigo 15:

"a admissão dos expostos (2) à assistência, se fará por consignação direta, excluído o sistema de rodas."

Prescrevia ainda o artigo 16:

"as instituições destinadas a recolher a criar expostos, terão um registro secreto organizado de modo a respeitar e garantir o incógnito em que se apresentem e desejem manter os portadores de crianças a serem asiladas.
LEMOS DE BRITO, no seu livro "As Leis de Menores no Brasil" diz o seguinte a respeito do registro secreto:

"o registro secreto abre aos mais infelizes uma nova era, aos expostos dias menos amargos quando puderem compreender a imensidade do seu infortúnio".

No Livro de ALVARENGA NETTO, Código de Menores encontra-se o seguinte comentário:

"a exclusão da roda estabelecida no art. 15, é incontestavelmente digna de louvores. A "roda" é um incentivo ao crime, uma chaga moral incompatível com a civilização moderna e já na sesssão de $1 .^{\circ}$ de setembro de 1922 do I Congresso de Proteção à Infância, foi aprovado que em todos os Estados do Continente Americano sejam suprimidas as chamadas Rodas de Expostos e em curto prazo substituídas pelos Instituos denominados registros livres".

No jornal Folha da Noite de São Paulo, 1. ${ }^{2}$ ed. do dia 23 de fevereiro de 1946, no artigo "A Roda dos Enjeitados", encontra-se o seguinte:

"... em cada criança abandonada pode ser lida uma história de mulheres chorando, da família blasfemando, de juras quebradas, de doenças graves, de tentativas de suicídio, de ameaças de morte, de fraquesa que é sempre chamada para encobrir atos pelos quais os preconceitos da sociedade fria e incompreensível a condenaria ao degredo moral".

Até 1916 o Instituto a Adoção fol desconsiderado. Nesta data foi aprovado o Código Civil Brasileiro, tendo suas bases no Direito Romano e no Direito Francês. O Instituto da Adoção - Capítulo $\mathrm{V}$, ficou assim estabelecido:

Art. 368 - Só os maiores de 50 anos

(2) Segundo o art. 14 do Código de Menores são considerados expostos os infantis abandonados até sete anos de idade, encontrados em estado de abandono, onde quer que seja. 
JŌRGE, D.R. - Histórico e aspectos legais da adoção no Brasil. Rev. Bras. Enf., RJ, $28: 11-22,1975$

sem prole legítima ou legitimada podem adotar.

Art. 369 - $\mathrm{O}$ adotante há de ser, pelo menos 18 (dezoito) anos mais velho que 0 adotado.

Art. 370 - Ninguém pode ser adotado por duas pessoas, salvo se forem marido e mulher.

Art. 371 - Enquanto não der contas de sua administração, e saldar o seu alcance, não pode o tutor ou curador adotar o pupilo, ou o curatelado.

Art. 372 - Não se pode adotar sem o consentimento da pessoa, debaixo de cuja guarda estiver o adotando, menor ou interdito.

Art. 373 - O adotado, quando menor, ou interdito, poderá desligar-se da adoção no ano imediato ao em que cessar a interdição, ou a menoridade.

Art. 374 - Também se dissolve o vínculo da adoção:

I - Quando as duas partes convierem.

II - Quando o adotado cometer ingratidão contra o adotante.

Art. 375 - A adoção far-se-á por escritura pública, em que se não admite condição, nem termo.

Art. 376 - O parentesco resultante da adoção limita-se ao adotante e ao adotado, salvo quanto aos impedimentos matrimoniais, a cujo respeito se observará o disposto no art. 182 n. ${ }^{a}$ III e IV.

Art. 377 - A adoção produzirá os seus efeitos ainda que sobrevenham filhos ao adotante, salvo se pelo fato do nascimento, ficar provado que o filho estava concebido no momento da adoção.

Art. 378 - Os direitos e deveres que resultam do parentesco natural não se extinguem pela adoção, exceto o pátrio poder, que será transferido ao pai natural para o adotivo.

Estava, portanto, criado o Instituto da Adoção no Brasil, cercado de precauções e restrições, refletindo uma filosofia ultrapassada. A criança não era benefi- ciada, pois o limite mínimo da idade do adotante era de 50 anos. Pouco valor social tinha assim, a medida da adoção. As dificuldades impostas pela lei fizeram com que muitos casais registrassem filhos alheios como próprios, recorrendo à maneira mais simples, ainda que se tratasse de delito previsto no Código Penal, art. 332.

Posteriormente, estudiosos como o Dr. GUSTAVO LESSA (1945), tentaram mostrar, aos legisladores brasileiros, a necessidade de uma lei que visasse os interesses da criança. Em 1948 o Departamento Nacional da Criança apresentava na I Jornada de Pediatria e Puericultura um Ante-Projeto de Lei de Adoção, da autoria dos drs. Maria Olinto, Flamarion Costa, Gustavo, Lessa, Desembargador Saboia Lima, Professores Olinto de Oliveira e Helena Antipoff.

Somente em 1953 é que esse Ante-Projeto foi encaminhado, pelo Senador Mozart Lago, à Câmara Federal. Após sofrer várias emendas foi aprovado pela Lei 3.133 , de 8 de maio de 1957. O texto é o seguinte:

"Art. 1. ${ }^{\circ}$ - Os arts. 368, 369, 372, 374 e 377 do Capítulo V - da Adoção do Código Civil, passarão a ter a seguinte redação:

Art. 368 - Só os maiores de 30 (trinta) anos podem adotar.

Parágrafo único - Ninguém pode adotar, sendo casado, senão decorridos 5 (cinco) anos após o casamento.

Art. 369 - O adotante há de ser, pelo menos, 16 (dezesseis) anos mais velho que 0 adotado.

Art. 372 - Não se pode adotar sem o consentimento do adotado ou de seu representante legal, se for incapaz ou nascituro.

Art. 374 - Também se dissolve o vínculo da adoção:

I - Quando as duas partes convierem.

II - Nos casos em que é admitida a deserdação. 
JORGE, D.R. - Histórico e aspectes legais da adoção no Brasil. Rev. Bras. Enf., RJ, $28: 11-22,1975$

Art. 377 - Quando o adotante tiver filhos legítimos, legitimados ou reconhecidos, a relação de adoção não envolve a de sucessão hereditária.

Art. $2 .^{\circ}$ - No ato da adoção serão declarados quais os apelidos de família que passará a usar o adotado.

Parágrafo único - $\mathrm{O}$ adotado poderá formar seus apelidos conservando os dos pais de sangue; ou acrescentando os do adotante; ou ainda, somente os do adotante, com exclusão dos apelidos dos pais de sangue:

Art. $3 .^{\circ}$ - Esta lei entrará em vigor na data de sua publicação, revogadas as disposições em contrário."

Estes novos preceitos legais aumentaram a possibilidade de adotar, reduzindo o limite mínimo de idade dos adotantes de 50 para 30 anos. Tanto os que não têm filhos, como os que têm, os solteiros e desquitados, por esta nova lei, podem adotar.

Quanto à sucessão hereditária, a nova lei exclui o filho adotivo, no caso do adotante ter filhos legítimos ou reconhecidos.

$\mathrm{Na}$ legislação anterior o filho adotivo recebia a metade dã herança cabível aos filhos legítimos ou reconhecidos; na presente lei, no caso, ele é excluído.

Além disso, em face do art. 378, a mãe que abandona seu filho perde com a adoção, somente os direitos e obrigações derivadas do pátrio poder, que se transferem para o pai adotivo, permanecendo íntegros todos os demais oriundos do parentesco natural.

As novas disposições legais, dando tratamento desigual para o filho adotivo, não agradaram os adotantes. Muitos casais preferiram desistir da adoção a trazer uma criança, criá-la, para depois deixá-la desprotegida, vivendo da caridade de seus irmãos de criação, isto se lhe lhe fizessem a caridade. $E$ ainda mais conforme dita o art. 378 , continua o vínculo a relação de parentesco entre o adotado e seus parentes de origem.

DIAS (1964), muito acertadamente, diz:

“' preciso lembrar que não é o sangue mas a convivência que gera 0 amor filial. Assim sendo a afeição que o adotado tem por aqueles que considera como pais é tão sincera e tão acentuada como a que outros sentem por seus pais legítimos. Imagine-se em tal situação, quais poderiam ser os efeitos que o impacto da revelação poderia trazer ao espírito em formação do menor adotado! Toda sua vida poderia, a rigor, vir a ser afetada."

A nossa experiência profissional, confirma as palavras do autor acima porque conhecemos casais que amaram seus filhos adotivos tanto quanto os seus filhos legítimos. Lembramos de ter acompanhado o desespero de uma senhora que perdera seu filho adotivo, de 19 anos de idade, segundo ela, mais carinhoso do que seus próprios filhos. Essa "mãe" naturalmente, não deixaria aquele filho ao completo desamparo, após sua morte. Porque exclui, de direitos familiares, um ser que trouxe grandes alegrias.

Quantos casais consideram e amam os filhos de seus filhos adotivos como verdadeiros netos de sangue! Se pudessemos fazer um levantamento, com surpresa, veríamos que são muitos. O ser humano que tem capacidade de amparar os animais, tem maior capacidade para amar outro ser humano que criou.

Certa vez ouvimos de um casal que havia adotado duas crianças, que na ocasião já eram moços, que a felicidade que aqueles filhos lhes havia proporcionado era muito grande pelo pouco que tinham feito por eles.

Em 1965 um novo dispositivo legal deu um grande impulso na solução de muitos problemas não previstos pela Lei n. ${ }^{\circ}$ $3.133 / 57$. Trata-se da Lei $n .^{\circ} 4.655$, de 2 de junho de 1965, aprovada após tramitação na Câmara dos Deputados, por 10 
JORGE, D.R. - Histórico e aspectos legais da adoção no Brasil. Rev. Bras. Enf., RJ, $28: 11-22,1975$

longos anos, do Projeto de Lei n. ${ }^{\circ}$ 56, apresentado por Jaeder Albergária, em 1955, Segundo Chaves (1966) o Brasil foi o segundo país do mundo a seguir o exemplo da França, inculpindo em sua legislação, uma das mais brilhantes conquistas, a Lei n. $.^{\circ} 4.655 / 65$, que dispõe sobre a legitimação adotiva e cujo texto é o seguinte:

Art. $10^{\circ}$ - E permitida a legitimação adotiva do infante exposto, cujos pais sejam desconhecidos ou hajam declarado por escrito que pode ser dado, bem como do menor abandonado propriamente dito até 7 (sete) anos de idade, cujos pais tenham sido destituídos do pátrio poder; do órfão da mesma idade, não reclamado por qualquer parente por mais de um ano; e, ainda, do filho natural reconhecido apenas pela mãe, impossibilitada de prover a sua criação.

$\S 10^{\circ}$ - Será também permitida a legitimação adotiva em favor do menor com mais de 7 (sete) anos, quando à época em que completou essa idade já se achava sob a guarda dos legitimantes, mesmo que estes não preenchessem então, as condições exigidas.

$\S 2 .^{\circ}$ - A legitimação só será deferida após um período mínimo de 3 (três) anos de guarda do menor pelos requerentes. Para esse efeito, será computado qualquer periodo de tempo, desde que a guarda se tenha iniciado antes de completar o menor 7 (sete) anos.

Art. $2 .^{\circ}$ - Somente poderão solicitar a legitimação adotiva dos menores referidos no artigo anterior os casais cujo matrimônio tenha mais de 5 (cinco) anos e dos quais pelo menos um dos cônjuges tenha mais de 30 (trinta) anos de idade, sem filhos legítimos, legitimados ou naturais reconhecidos.

Parágrafo único - Será dispensado o prazo de 5 (cinco) anos de matrimônio, provada a esterilidade de um dos cônjuges, por perícia médica, e a estabilidade conjugal.
Art. 3. ${ }^{\circ}$ - Autorizar-se-á, excepcionalmente, a legitimação ao viúvo, ou viúva, com mais de 35 (trinta e cinco) anos de idade, provando que o menor esteja integrado em seu lar e onde viva há mais de 5 (cinco) anos.

Art. $4 .^{\circ}$ - Os cônjuges desquitados, havendo começado a guarda do menor, no período de prova, na constância do matrimônio e concordando sobre ele após a terminação, obedecido, quanto à guarda e proteção, o disposto nos arts. 325, 326 e 327 do Código Civil.

Art. $5:^{\circ}$ - Com a petição serão oferecidos certidão de casamento, atestado de residência, folha de antecedentes, prova de idoneidade moral e financeira, atestado de inexistência de filhos, prova de abandono do menor e destituição do Pátrio Poder, bem como atestado de sanidade física, provando que nenhum dos requerentes sofre de moléstia contagiosa.

$\S 10^{\circ}$ - O Juiz, tendo em vista as conveniências do menor, o seu futuro bem estar, ordenará, de ofício, ou a requerimento do Ministério Público, as diligências e sindicâncias que julgar necessárias, correndo contudo o processo em segredo de justiça.

$\S 2 .^{\circ}$ - Feita a prova e concluídas as diligências, o Juiz, ouvido o Ministério Público, proferirá sentença da qual caberá recurso de reexame para o Tribunal de Justiça, com efeito suspensivo.

Art. $6 .^{\circ}$ - A sentença deferindo a legitimação terá efeitos constitutivos, devendo ser inscrita, mediante mandado, no Registro Civil, como se se tratasse de registro fora de prazo, no qual se consignará os nomes dos pais adotivos como pais legítimos e os nomes dos ascendentes dos mesmos. O mandado será arquivado, dele não podendo o oficial fornecer certidão.

$\S 10^{\circ}$ - Nas certidões do registro nenhuma observação poderá constar sobre a origem do ato.

$\S 2 .^{\circ}$ - O registro original do menor 
JORGE, D.R. - Histórico e aspectos legais da adoção no Brasil. Rev. Bras. Enf., RJ, $28: 11-22,1975$

será anulado, também por mandado do Juiz, o qual será arquivado. (VETADO).

$\S 3 .^{\circ}$ - Feita a inscrição, cessam os vínculos da filiação anterior, salvo para os efeitos do art. 183 do Código Civil.

Art. 7. ${ }^{\circ}$ - A legitimação adotiva é irrevogável, ainda que aos adotantes venham a nascer filhos legitimos, aos quais estão equiparados os legitimados adotivos, com os mesmos direitos e deveres esabelecidos em lei.

Art. $8^{\circ}$ - A violação do segredo estabelecido neste capítulo, salvo decisão judicial, sujeitará o funcionário responsável às penas do art. 325 do Código Penal.

Art. $9 .^{\circ}$ - O legitimado adotivo tem os mesmos direitos e deveres do filho legítimo, salvo no caso de sucessão, se concorrer com o filho legítimo superveniente à adoção. (Código Civil, $\S 2 .^{\circ}$ do art. 1605).

$\S 10^{\circ}$ - $\mathrm{O}$ vínculo da adoção se extende à família dos legitimantes, quando os seus ascendentes derem adesão ao ato que o consagrou.

$\S 2 .^{\circ}$ - Com a adoção cessam os direitos e obrigações oriundos da relação de parentesco do adotado com a família de origem.

Art. 10 - A decisão confere ao menor o nome do legitimante e pode determinar a modificação do seu prenome, a pedido dos cônjuges.

Art. 11 - Esta lei entre em vigor na data de sua publicação.

Art. 12 - Revogam-se as disposições em contrário.

Legitimidade adotiva é diferente da adoção, porque seus efeitos são mais duradouros e profundos. O adotado é desligado da família de origem.
Sobre a Legitimidade adotiva e adoção CHAVES (1966) comenta e define:

"a legitimidade adotiva é a forma mais avançada de integração de crianças abandonadas ou expostas, em lares substitutos. Somente a legitimação adotiva veio resolver o problema dos menores abandonados, que não podiam ser incorporados definitivamente como filhos pela família que os desejasse adotar, a não ser pelo meio fraudulento e criminoso de fazer declarar como filhos legítimos atribuindo-lhes falsa qualidade e ainda dando margem a futura anulação do registro por parte dos verdadeiros pais que tinham antes abandonado os filhos, criando para estes uma situação social e moral inteiramente injustificável."

"legitimidade adotiva é a outorga judicial de efeitos constitutivos e com as condições de segredo, irrevogabilidade e total desligamento da família de sangue, obedecidos os requisitos fixados em lei a um menor de sete anos de idade, abandonado, órfão ou desamparado, do estado legítimo de um casal excepcionalmente de pessoa viúva, com ressalva dos impedimentos matrimoniais e do direito de sucessão se concorrer com filho legítimo superveniente."

"adoção é a convocação de um estranho, que tanto pode ser um menor como um homem ou uma mulher, mesmo casado dentro de uma família, ou ao lado de uma pessoa que tenha dezesseis anos a mais sem a preopação de apagar a lembrança e a condição de estranho."

A grande diferença entre as duas é que a ligitimidade adotiva, objetiva a integração de uma criança exclusivamente numa família, com a preocupação primordial de fazê-lo esquecer por completo sua condição de elemento estranho.

O quadro a seguir mostra as principais características dos processos de adoção e legitimidade adotiva. 


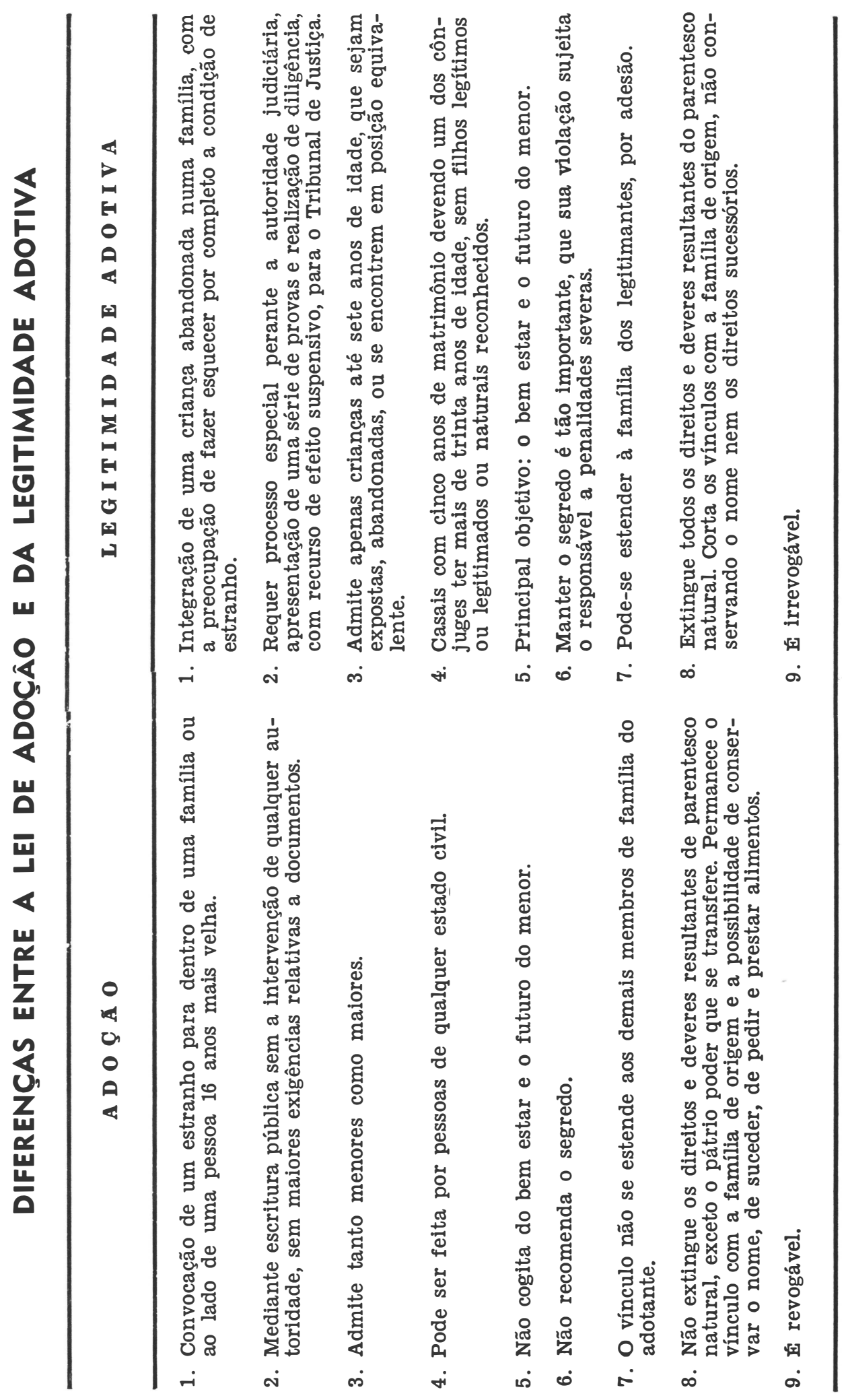


JORGE, D.R. - Histórico e aspectos legais da adoção no Brasil. Rev. Bras. Enf., RJ, $28: 11-22,1975$

Pelo exposto, entende-se que a legitimação adotiva veio melhorar a situação de menores abondonados que não podiam ser integrados como filhos dos adotantes, a não ser por meios ilegais sujeitos a anulação do ato e aplicação de sanções penais.

Segundo comentário de Chaves, sobre a Lei $n .^{\circ} 4.655 / 65$, restam imperfeições ainda, porém, as vantagens sobrepujam as deficiências.

De fato a Lei $4.655 \mathrm{faz}$ as seguintes restrições: impede o direito de liitimado adotivo à sucessão no caso de sobrevir filho natural, não permite legitimar mais de uma criança, quem já possui filho natural, não pode legitimar e, não prevê a possibilidade de transformar o adotado em legitimado adotivo.

A lei uruguaia, permite a legitimação adotiva aos casais que já possuem filhos. O Código Civil Francês permite a legitimação adotiva de mais de uma criança. Talvez por esse motivo, na França a proporção de pedidos é de mil e quinhentas legitimações adotivas para 80 adoções (CHAVES 1966).

A lei brasileira põe limites, que impedem a integração de mais seres abandonados, e companhia para muitos fi- lhos únicos, complemento necessário para o seu desenvolvimento e educação.

Devido a estas limitações ainda muitos preferem o ato ilegal de registrar filho alheio como seu.

No caso da constatação de ilegalidades, usadas de má fé ou para contornar essas restrições, o Código Penal prevê penalidades para os crimes (autoria e co-autoria) contra o estado de filiação e falsificação de documentos, nos seguintes artigos:

Art. 266 - Promover no registro civil a inscrição de nascimento inexistente:

Pena: reclusão de dois a seis anos.

Art. 267 - Registrar como seu o filho de outrem; dar parto alheio como próprio; ocultar recém-nascido ou substituí-lo, suprimindo ou alterando direito inerente ao estado civil.

Pena: reclusão, até seis anos.

Art. 269 - Deixar em asilo de expostos, ou outra instituição de assistência, filho próprio ou alheio, ocultando-lhe a filiação ou atribuindo-lhe outra, com o fim de prejudicar direito inerente ao estado civil:

Pena: reclusão, até cinco anos e pagamento de cinco a trinta dias de multa.

\section{CONCLUSÃo}

\section{Considerando que:}

1. enfermeiras e obstetrizes recebem com freqüência solicitação de ajuda para adoção de criança;

2. é alta a porcentagem de profissionais que desconhece os aspectos legais da adoção no Brasil;

3. enfermeiras e obstetrizes são responsáveis pela orientação adequada de seus pacientes e clientes, visando a as- sistência integral às suas necesidades;

4. nos currículos de graduação em enfermagem e obstetricia o tema da adoção não é sistematicamente abordado.

\section{Recomendamos que}

1. nos programas de enfermagem obstétrica, tanto do ciclo profissional como no de habilitação em obstetrícia, seja incluído o tema: - Adoção e Legitimação adotiva no Brasil. 
JORGE, D.R. - Histórico e aspectos legais da adoção no Brasil. Rev. Bras. Enf., RJ, $28: 11-22,1975$

\section{BIBLIOGRAFIA}

BARREIRA, Dolor - A Adoção e a recente Lei n. 3.133. Revista Forense, 54 (174): 54-59, 1954.

BEVILACQUA Clovis - Adopção - Soluçōes Práticas de Direito (Pareceres). Rio de Janeiro, Correa Bastos, 1923 .

\section{- - Adopção antes do Código Civil -} Soluções Práticas de Direito (Pareceres), Rio de Janeiro, Correa Bastos, 1923.

- O Fundamento jurídico do recocimento da adopção. Revista de Direito, 58:60, 1920.

Brasil, Leis, Decretos, etc. - Colesão de Leis do Império do Brasil. Rio de Janeiro, Tipografia Nacional, 1828 e 1890.

- Código Civil, 24. ${ }^{\text {— }}$ ed., Saraiva, 1973.

- Código de Menores, 2. ed., Saraiva, 1973.

- Código Penal, 2. ed., Saraiva, 1973.

- Coleção de Leis da República dos Estados Unidos do Brasil, Rio de Janeiro, Departamento de Imprensa Nacional, 1957 e 1965.

CHAVES, Antonio - A legitimação adotiva Revista dos Tribunais, 55 (368) : 390395, 1966.

CHAVES, Antonio - Adoção e legitimação adotiva - Dissertação para concurso à cátedra de Direito Civil da Facul- dade de Direito da USP. Revista dos Tribunais, 54, 1965.

- A legitimação adotiva. Revista da Faculdade de Direito da USP, 62 (2) :335-346, 1967.

DIAS, Aldo de Assis - Da adoção e da legitimação adotiva. Revista dos Tribunais, 53 (348) : 7-13, 1964.

LEME, Lino de Morais - Adoção antes do Código Civil. Revista dos Tribunais, 52 (335):82-83, 1963.

LESSA, Gustavo - A adoção da criança e a legislação brasileira. Rio de Janeiro, D.N.Cr., 1945 (datilografado).

MINISTセRIO DA SAÚDE/D.N.Cr. - AnteProjeto da Lei sobre Adoção. I Jornada de Pediatria e Puericultura, 1948. (Material datilografado).

MONCORVO, Arthur Filho - História da Proteção à Infância no Brasil - 1500/ 1922, 2. ${ }^{\text {a }}$ ed., Rio de Janeiro, Paulo Pongetti, 1926.

PINTO, Souza A. - Gênesis e desenvolvimento histórico do Instituto da Adoção. Estudos Sociais e Jurídicos, $3^{\circ}$ opúsculo, Recife, Imprensa Industrial, s/d.

SILVA, A. J. da - Relatório da Santa Casa de Misericórdia do Recife, Pernambuco, 1900. 